\title{
Peningkatan Pemahaman Siswa Kelas Vi Materi Sistem Peredaran Darah Manusia Menggunakan Media Interaktif
}

\author{
Yusi Puspitasari \\ Guru Kelas, Dinas Pendidikan Pemuda dan Olahraga Kabupaten Temanggung \\ *Coresponding author: yusibraga@gmail.com
}

\section{ARTICLEINFO}

Article history:

Received: 24 Mei 2019

Accepted: 12 September 2019

\section{Keywords:}

pemahaman siswa, sistem peredaran darah, media

interaktif

\begin{abstract}
ABSTRAK
Sistem peradaran manusia merupakan materi yang cukup sulit dipahami oleh siswa karena organ-organ yang dipelajari tidak bisa dilihat langsung oleh siswa sehingga membutuhkan visualisasi dalam pembelajarannya. Pembelajaran yang dilakukan guru selama ini hanya menggunakan bahan ajar cetak berupa buku. Guru terlalu banyak ceramah sehingga seringkali siswa merasa bosan. Kurnagnya penggunaan media pembelajaran menyebabkan siswa mengalami kesulitan dalam memahami materi tersebut. Tujuan peneliti dalam penelitian ini adalah untuk memperbaiki kinerja guru dalam proses pembelajarannya, meningkatkan pemahaman serta hasil belajar siswa tentang sistem peredaran darah manusia pada kelas VI SD Negeri Balesari menggunakan media interaktif. Berdasarkan hasil penelitian yang dilakukan terlihat bahwa penggunaan media interaktif dapat meningkatkan pemahaman serta hasil belajar siswa dalam materi sistem peredaran darah manusia. Hasil evaluasi pada kondisi awal yang semula nilai rataratanya 55 dengan ketuntasan sebanyak 7 siswa dengan persentase $25 \%$ meningkat pada siklus I dengan nilai ratarata yang diperoleh adalah 71,50 dengan ketuntasan sebanyak 16 siswa dengan persentase $57,14 \%$ kemudian pada siklus ke II diperoleh rata-rata nilai sebanyak 85,36 dengan ketuntasan sebanyak 26 siswa dengan persentase $92,86 \%$.
\end{abstract}

\section{PENDAHULUAN}

Ilmu Pengetahuan Alam merupakan mata pelajaran yang mempelajari tentang tumbuhan, hewan dan manusia. Salah satu materi dalam mata pelajaran IPA adalah sistem peredaran darah manusia. Isi materinya berupa alat peredaran darah, jenis peredaran darah, dan penyakit yang berhubungan dengan peredaran darah. Proses belajar mengajar di SD Negeri Balesari khususnya mata pelajaran IPA masih kurang menarik, karena proses pembelajaran yang sejak dulu masih sama, guru menjelaskan di depan dan siswa 
mendengarkan atau memperhatikan. Sistem pembelajaran seperti ini membuat siswa merasa bosan dan tidak tertarik untuk memperhatikan penjelasan guru. Dengan demikian pemahaman serta hasil belajar siswa tentang sistem peredarahan darah masih cukup rendah. Dilihat dari hasil rata-rata belajar dari 28 siswa kelas VI baru mencapai 55,00.

Berdasarkan permasalahan tersebut, dibutuhkan sebuah aplikasi sistem peredaran darah manusia yang interatif sehingga lebih menarik dengan memanfaatkan video pembelajaran sebagai media pembelajaran yang dapat menjelaskan materi sistem peredaran darah manusia sebagai sarana pendukung untuk membantu kegiatan belajar mengajar, dimana siswa dapat melihat alur peredaran darah dengan melihatnya secara langsung melalui video.

\section{Rumusan Masalah}

Apakah media interaktif dapat meningkatkan pemahaman siswa pada materi sistem peredaran darah manusia di kelas VI SD Negeri Balesari Kecamatan Bansari Kabupaten Temanggung?

\section{Tujuan Penelitian}

Berdasarkan latar belakang dan rumusan masalah di atas, maka penelitian ini bertujuan (1) untuk mengetahui apakah dengan media interaktif dapat meningkatkan pemahaman siswa tentang sistem peredaran darah manusia pada siswa kelas VI SD Negeri Balesari; (2) untuk mengetahui seberapa besar peningkatan pemahaman sista tentang sistem peredaran darah manusia pada siswa kelas VI SD Negeri Balesari.

\section{Manfaat Penelitian}

Manfaat penelitian (1) bagi guru : memberikan sumbangan pemikiran dalam usaha meningkatkan kualitas pembelajarannya; (2) bagi siswa : memberikan pengalaman yang bermakna dalam penggunaan media interaktif pada mata pelajaran Ilmu Pengetahuan Alam sehingga pemahaman siswa dapat meningkat; (3) bagi sekolah : memberikan sumbangan pemikiran dan alternatif langkah-langkah pembelajarannya.

\section{KAJIAN TEORI DAN HIPOTESIS TINDAKAN \\ Pengertian Pemahaman}

Pemahaman menurut Sadiman (1996:109) ialah suatu kemampuan seseorang dalam mengartikan, menafsirkan, menerjemahkan, atau menyatakan sesuatu dengan caranya sendiri tentang pengetahuan yang pernah diterimanya. Suharsimi (2009:118-137) mendefinisikan pemahaman (comprehension) ialah bagaimana seorang mempertahankan, membedakan, menduga (estimates), menerangkan, memperluas, menyimpulkan, menggeneralisasikan, memberikan contoh, menuliskan kembali, dan memperkirakan. Sedangkan menurut Kamus Lengkap Bahasa Indonesia, pemahaman merupakan sesuatu hal yang kita pahami dan kita mengerti dengan benar.

Dari pendapat para ahli di atas, dapat disimpulkan bahwa pemahaman merupakan kemampuan seseorang dalam mempertahankan, membedakan, menduga, menerangkan, menafsirkan, menentukan, memperluas, menyimpulkan, menganalisis, memberi contoh tentang sesuatu.

\section{Media Interaktif}

Media pembelajaran adalah sarana fisik untuk menyampaikan isi atau materi pembelajaran seperti buku, film, video, slide, dan sebagainya (Komala, Suryanda, \& Lismana, 2016; Nisa, Djamahar, \& Evriyani, 2015). Menurut Munadi (2008, 7) media pembelajaran merupakan segala sesuatu yang dapat menyampaikan dan menyalurkan pesan dari sumber secara terencana sehingga tercipta lingkungan belajar yang kondusif dimana penerimanya dapat melakukan proses belajar secara efisien dan efektif. 
Interaktif ialah hal yang terkait dengan komunikasi dua arah atau suatu hal bersifat saling melakukan aksi, saling aktif dan saling berhubungan serta mempunyai timbal balik antara satu dengan lainnya (Warsita, 2008). Media interaktif merupakan media yang memberikan pembelajaran interaktif dalam bentuk 3D, suara, gerak, video, animasi, dan menciptakan interaksi (Cheng, 2009). Media pembelajaran interaktif adalah suatu sistem penyampaian pengajaran yang menyajikan materi video rekaman dengan pengendalian komputer kepada penonton (siswa) yang tidak hanya mendengar dan melihat video dan suara, tetapi juga memberikan respon yang aktif, dan respon itu yang menentukan kecepatan sekuensi penyajian (Seels Glasgow dalam Arsyad, 2002:36).

Dari beberapa pengertian di atas dapat disimpulkan bahwa media interaktif merupakan alat bantu berbasis multimedia yang bisa menjabarkan pesan atau informasi dari guru ke siswa yang dalam prosesnya terjadi komunikasi aktif dua arah antara multimedia dengan pengguna atau yang tujuannya untuk mempermudah proses pembelajaran.

\section{Hakikat Pembelajaran IPA}

Pendidikan Ilmu Pengetahuan Alam memiliki peranan penting dalam pembentukan kepribadian dan perkembangan intelektual siswa. Perkembangan psikologis anak usia SD merupakan masa dimana mereka mempunyai rasa keingintahuan yang besar. Menurut Soedijarto (1993:53) dalam Sumaji (2006) menyatakan bahwa pendidikan sains bukanlah merupakan transfer pengetahuan dari guru sebagai sumber pengetahuan kepada anak sebagai siswa. Menurut Carin (1997:4-5) dalam Syah menyatakan bahwa hakikat IPA itu sendiri yang dapat dipandang sebagai proses, produk dan pengembangan sikap. Dimensi proses IPA menurut guru untuk melibatkan siswa secara aktif dalam kegiatan-kegiatan dasar yang biasa dilakukan oleh para ilmuwan dalam upaya memperolah pengetahuan, kegiatan dasar ini sering disebut sebagai metode ilmiah (scientific method) dari keterampilan proses, melalui proses IPA akan ditemukan produk IPA berupa fakta, konsep, hukum, dan teori yang diaplikasikan ke dalam teknologi.

Berdasarkan pernyataan di atas dapat disimpulkan bahwa hakikat pembelajaran IPA di SD adalah pembelajaran IPA bukan sekedar penguasaan konsep, prinsip hukum atau teori semata melainkan suatu proses dengan cara mengembangkan keterampilan proses dan sikap ilmiah untuk mendapatkan konsep-konsep ilmiah tentang alam semesta.

\section{Sistem Peredaran Darah Manusia}

Sistem peredaran darah adalah suatu sistem organ yang berfungsi memindahkan zat ke dan dari sel. Organ pemompa darah adalah jantung. Jantung terdiri dari 4 ruang yaitu bilik kanan (ventrikel dexter), bilik kiri (ventrikel sinister), serambi kanan (atrium dexter), dan serambi kiri (atrium sinister). Fungsi jantung adalah (1) memompa darah melalui pembuluh darah ke seluruh tubuh; (2) memompa darah ke paru-paru untuk mengambil oksigen; (3) menerima darah dari seluruh tubuh; (4) membantu membuang limbah sisa metabolisme berupa gas $\mathrm{CO}_{2}$.

Terdapat dua sistem peredaran darah, yaitu peredaran darah kecil dan peredaran darah besar.

1. Peredaran darah kecil adalah peredaran darah yang dimulai dari jantung ke paru-paru kemudian kembali lagi ke jantung.

$$
\text { Jantung } \longrightarrow \text { Paru-paru } \longrightarrow \text { Jantung }
$$

Prosesnya : Darah dari bilik kanan menuju arteri pulmonalis (darah kaya CO2) kemudian diteruskan ke paru-paru, selanjutnya menuju vena pulmonalis (darah kaya O2), dan berakhir ke serambi kiri. 
Bilik kanan $\longrightarrow$ Arteri pulmonalis (darah kaya $\mathrm{CO}_{2}$ )

Paru-paru

Vena pulmonalis (darah kaya $\mathrm{O}_{2}$ )

Serambi kiri

2. Peredaran darah besar

Aliran darah pada peredaran darah besar dimulai dari jantung ke seluruh tubuh dan kembali lagi ke jantung. ke jantung.

\begin{tabular}{|l} 
Jantung $\longrightarrow$ Seluruh tubuh $\longrightarrow$ Jantung \\
\hline
\end{tabular}

Prosesnya : Darah dari bilik kiri menuju aorta kemudian diedarkan ke suluruh tubuh, selanjutnya menuju vena kava superior/interior (darah kaya CO2) dan berakhir di serambi kanan.

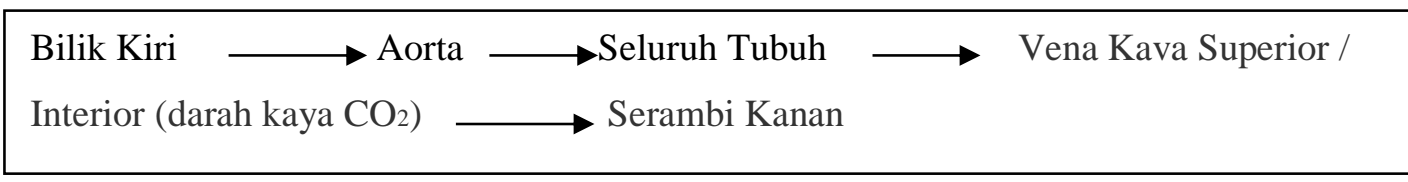

Penyakit yang mengganggu peredaran darah yaitu (1) Anemia merupakan penyakit kekurangan hemoglobin di dalam darah; (2) Leukimia juga dikenal dengan sebutan kanker darah yang disebabkan oleh kelebihan produksi sel darah putih yang jumlahnya abnormal. Sel darah putih tersebut akan memakan eritrosit dan menyebabkan menurunnya jumlah eritrosit; (3) Hipertensi ini disebut juga dengan penyakit tekanan darah tinggi. Seseorang disebut menderita hipertensi jika tekanan sistol dan diastolnya lebih dari 140/90 mmHg. Jika terlalu tinggi, dapat menyebabkan pembuluh darah pecah.

\section{Penelitian yang Relevan}

Penelitian yang dilakukan oleh Dinar Arena Tiari pada Program Studi Magister Teknologi Pendidikan FKIP Universitas Sebelas Maret Surakarta Tahun 2016 yang berjudul "penerapan media interaktif untuk meningkatkan motivasi dan hasil belajar ipa materi struktur organ tubuh manusia dan fungsinya". Persamaan penelitian yang dilakukan oleh Dinar Arena Tiari dengan penelitian yang dilakukan peneliti terletak pada penggunaan media interaktif sebagai media pembelajaran. Bedanya pada materi yang diambil.

\section{KERANGKA BERPIKIR}

Pada kondisi awal dalam menyampaikan materi sistem peredaran darah manusia, guru masih menggunakan metode ceramah yang membuat siswa tidak tertarik untuk memperhatikan sehingga pemahaman siswa tentang sistem peredaran darah manusia masih rendah. Agar pemahaman siswa meningkat maka diperlukan adanya tindakan. Tindakan untuk meningkatkan pemahaman siswa itu dengan menggunakan media interakitf. Penerapan media interaktif ini dilakukan dalam dua siklus. Pada kondisi akhir setelah menggunakan media interaktif pemahaman siswa meningkat. 
Berdasarkan kajian teoretik disusun kerangka berpikir sebagai berikut :

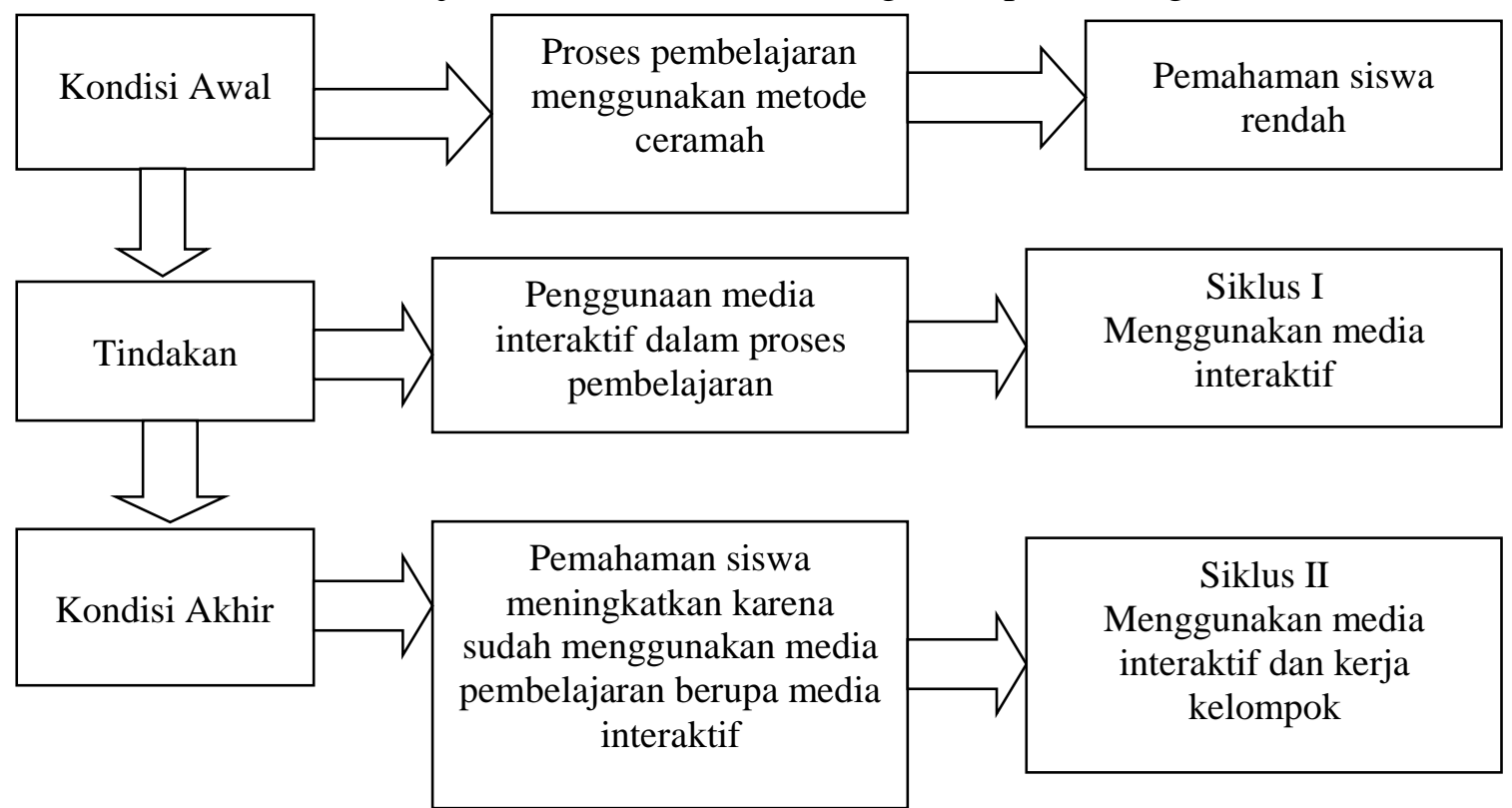

Gambar 1. Kerangka Berpikir

Berdasarkan kajian teori dan kerangka berpikir di atas, diduga bahwa melalui penggunaan media interaktif dapat meningkatkan pemahaman siswa tentang sistem peredarah darah manusia.

\section{HIPOTESIS TINDAKAN}

Berdasarkan kajian teori dan kerangka berpikir dalam penelitian ini, maka dirumuskan hipotesis sebagai berikut : penggunaan media interaktif dapat meningkatkan pemahaman siswa tentang sistem peredaran darah manusia bagi siswa kelas VI SD Negeri Balesari Tahun 2018/2019.

\section{METODE}

Penelitian ini dilaksanakan di SD Negeri Balesari yang terletak di Kecamatan Bansari Kabupaten Temanggung. Penelitian ini berlangsung selama tiga bulan, mulai November 2018 sampai Januari 2019 menggunakan jenis perlakuan tindakan Classroom Action Research (Penelitian Tindakan Kelas).

Subjek penelitian ini adalah siswa kelas VI SD Negeri Balesari Kecamatan Bansari Kabupaten Temanggung Tahun Pelajaran 2018/2019. Siswa berjumlah 28 yang terdiri dari 15 putra dan 13 putri. Karakteristik siswa dalam proses pembelajaran cenderung pasif, serta kemampuan siswa dalam memahami materi sistem peredaran darah manusia masih rendah.

\section{Sumber Data}

Sumber data dalam penelitian ini melalui data nilai hasil belajar siswa sebelum siklus, siklus I dan siklus II, serta data hasil observasi siklus I dan siklus II.

\section{Teknik dan Alat Pengumpulan Data}

Teknik pengumpulan data yang digunakan dalam penelitian ini adalah (1) data kuantitatif dari tes formatif; (2) observasi, digunakan untuk mengamati keaktifan dan motivasi siswa selama proses pembelajaran.

Alat pengumpulan data dalam penelitian ini meliputi (1) tes tertulis, digunakan untuk mengumpulkan data siswa berkenaan dengan hasil belajar siswa pada materi sistem peredaran darah manusia; (2) lembar observasi, yang terdiri dari lembar observasi siswa 
dan lembar observasi guru.

\section{Analisis Data}

Analisis data penelitian ini bertujuan untuk mengetahui peningkatan pemahaman siswa tentang sistem peredaran darah manusia. Peningkatan pemahaman disini berupa hasil belajar pada kondisi awal, hasil belajar siklus pertama, dan hasil belajar pada siklus kedua. Hasil belajar merupakan data kuantitatif, karena itu analisis data yang digunakan adalah analisis deskriptif komparatif, yaitu membandingkan data kuantitatif. Yang dibandingkan adalah hasil belajar pada kondisi awal dibandingkan hasil belajar pada siklus pertama, kemudian hasil belajar siklus pertama dibandingkan hasil belajar siklus kedua, dan hasil belajar pada kondisi awal dibandingkan dengan hasil belajar pada siklus kedua.

\section{Indikator Keberhasilan}

Indikator keberhasilan dalam penelitian ini diperoleh $75 \%$ dari jumlah keseluruhan siswa kelas VI mendapatkan nilai lebih dari atau sama dengan 75 sesuai dengan KKM yaitu 75. Prosedur penelitian atau tindakan pada setiap siklusnya digambarkan sebagai berikut :

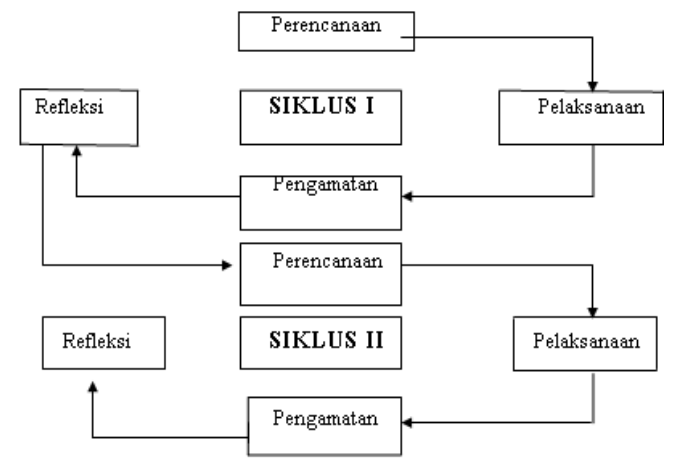

Gambar 2. Skema penelitian atau tindakan kelas

\section{HASIL DAN PEMBAHASAN \\ Deskripsi Kondisi Awal}

Berawal dari latar belakang masalah yang ada, peneliti melaksanakan penelitian dimulai dari perencanaan tindakan, pelaksanaan tindakan, observasi, dan refleksi mengungkapkan bahwa pembelajaran IPA materi sistem peredaran darah manusia kelas VI SD Negeri Balesari tahun pelajaran 2018/2019 pemahamannya masih rendah.

Berdasarkan hasil pengamatan pada kondisi awal menunjukkan bahwa hasil pembelajaran materi sistem peredaran darah pada siswa kelas VI dari 28 siswa, memperoleh nilai rata-rata 55. Hanya 7 siswa atau $25 \%$ siswa yang tuntas dengan mendapatkan nilai sesuai atau di atas KKM dan 21 siswa atau $75 \%$ siswa belum tuntas karena nilainya belum mencapai KKM. Siswa yang mendapatkan nilai 80 ada 2 atau $7,14 \%$ dengan keterangan (Tuntas), yang mendapatkan nilai 75 ada 5 atau $17,86 \%$ dengan keterangan (Tuntas), dan yang mendapatkan nilai di bawah 75 ada 21 atau $75 \%$ dengan keterangan (Belum Tuntas). Hal ini menjadi kendala bagi guru untuk melanjutkan pembelajaran pada materi berikutnya, sehingga peneliti akan memperbaiki proses pembelajaran untuk meningkatkan hasil belajar sesuai dengan KKM. Hasil belajar sistem peredaran darah manusia pada kondisi awal disajikan tabel sebagai berikut 
Tabel 1. Rentang Nilai hasil belajar kondisi awal

\begin{tabular}{|c|l|c|c|c|}
\hline No & Rentang nilai & Jumlah & Persentase & \multirow{2}{*}{ Keterangan } \\
\hline 1 & $95-100$ & - & $0 \%$ & \multirow{2}{*}{ Tuntas } \\
\cline { 1 - 2 } 2 & $85-94$ & - & $0 \%$ & \\
\hline 3 & $80-84$ & 2 & $7,14 \%$ & Belum Tuntas \\
\hline 4 & $75-79$ & 5 & $17,86 \%$ & - \\
\hline 5 & $\leq 74$ & 21 & $75 \%$ & 55 \\
\hline \multicolumn{2}{|l|}{ Jumlah } & 28 & $100 \%$ & 80 \\
\hline \multicolumn{2}{|l|}{ Rata-rata } & & 40 \\
\hline \multicolumn{2}{|l|}{ Nilai Tertinggi } \\
\hline
\end{tabular}

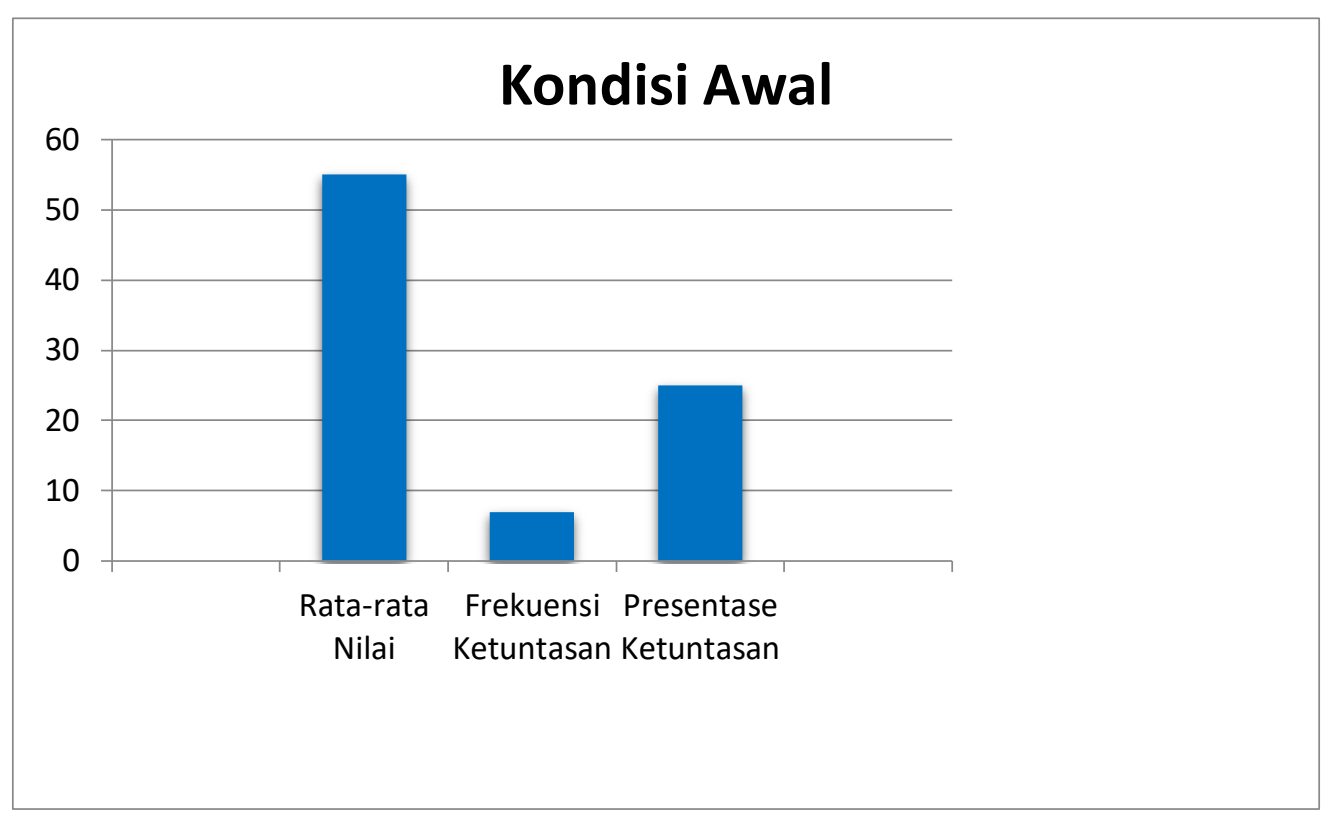

\section{Deskripsi Siklus I}

Grafik 1. Kondisi Awal

Siklus I dilakukan di kelas VI SD Negeri Balesari pada tanggal 3 Desember 2018, 7 Desember 2018, dan 11 Desember 2018. Hasil pengamatan pada siklus I dapat dilihat pada tabel berikut :

\section{a. Aspek Pehamahaman Terhadap K-13}

Data mengenai pemahaman kepala sekolah dan guru tentang K-13 diperoleh melalui kuesioner dan wawancara yang dilakukan peneliti terhadap para responden.

Tabel 2. Rentang Nilai hasil belajar Siklus I

\begin{tabular}{|c|c|c|c|c|}
\hline No & Rentang nilai & Jumlah & Persentase & Keterangan \\
\hline 1 & $95-100$ & - & $0 \%$ & \multirow{4}{*}{ Tuntas } \\
\hline 2 & $85-94$ & 3 & $10,71 \%$ & \\
\hline 3 & $80-84$ & 4 & $14,29 \%$ & \\
\hline 4 & $75-79$ & 9 & $32,14 \%$ & \\
\hline 5 & $\leq 74$ & 12 & $42,86 \%$ & Belum Tuntas \\
\hline \multicolumn{2}{|c|}{ Jumlah } & 28 & $100 \%$ & - \\
\hline \multicolumn{4}{|c|}{ Rata-rata } & 71,50 \\
\hline \multirow{2}{*}{\multicolumn{4}{|c|}{ Nilai Tertinggi }} & 90 \\
\hline & \multicolumn{3}{|c|}{ Nilai Terendah } & 58 \\
\hline
\end{tabular}




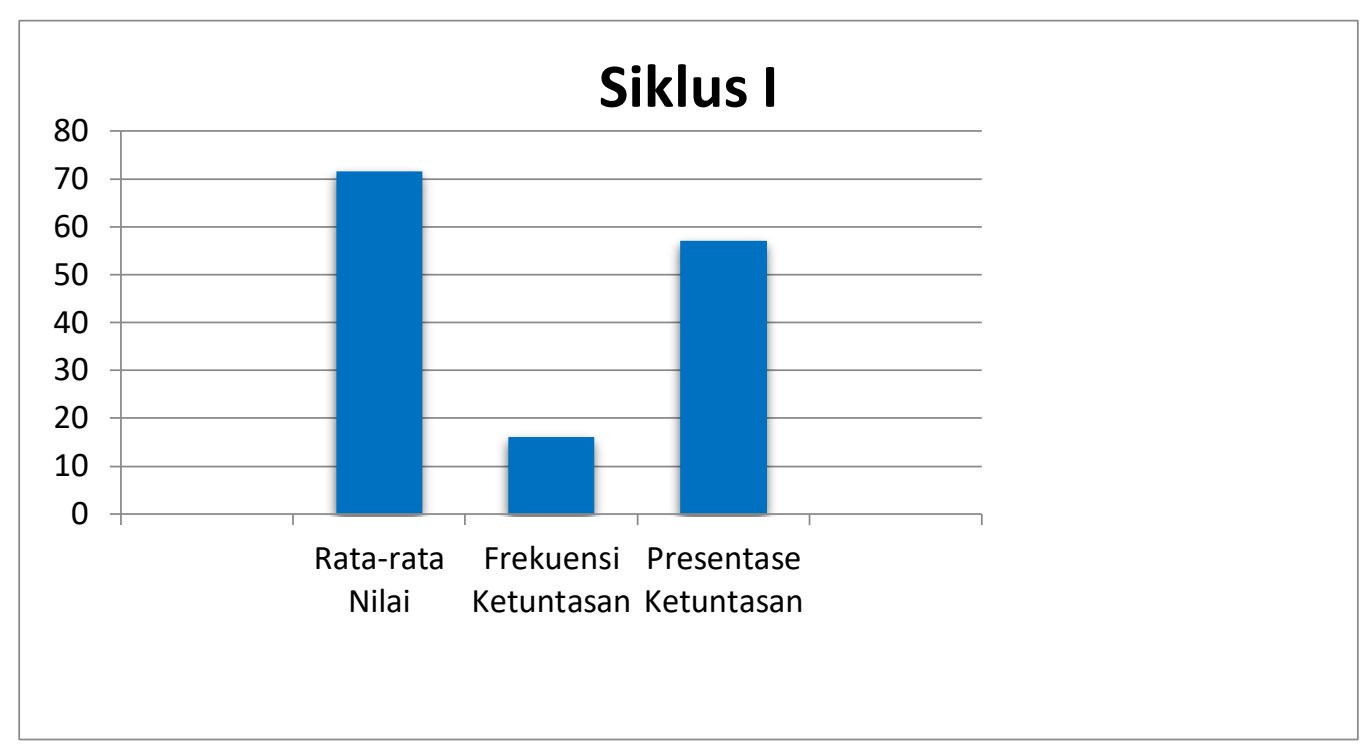

Grafik 2. Siklus I

Pengamatan nilai hasi belajar pada siklus I menunjukkan bahwa dari 28 siswa terdapat 13 siswa atau 46,43\% yang tuntas dengan mendapatkan nilai sesuai KKM dan 15 siswa atau 53,71\% yang belum tuntas dan mendapatkan nilai di bawah KKM. Siswa yang mendapatkan nilai 85-94 ada 3 dengan keterangan (Tuntas) dengan presentase $10,71 \%$. Siswa yang mendapat nilai $80-84$ ada 4 siswa dengan keterangan (Tuntas) dengan presentase 14,29\%. Siswa yang mendapat nilai $75-79$ ada 9 siswa dengan keterangan (Tuntas) dengan presentase $32,14 \%$. Siswa yang mendapatkan nilai di bawah KKM ada 12 siswa dengan keterangan (Belum Tuntas) dengan presentase $42,86 \%$.

Karena perbaikan pembelajaran pada Siklus I belum dapat maksimal dalam meningkatkan pemahaman konsep dan mengerjakan soal tentang materi sistem peredaran darah manusia, maka peneliti akan memperbaikai pembelajaran kembali pada Siklus II.

\section{Deskripsi Siklus II}

Berdasarkan Tindakan pada siklus I sudah terlihat ada peningkatan hasil belajar, namun hasilnya belum maksimal. Pelaksanaan tindakan pada siklus II dilaksanakan pada tanggal 17 Desember 2018, 24 Desember 2018, dan 3 Januari 2019. Hasil pengamatan pada siklus II dapat dilihat pada tabel berikut :

Tabel 3 Rentang Nilai Hasil Belajar Siklus II

\begin{tabular}{|c|c|c|c|c|}
\hline No & Rentang nilai & Jumlah & Persentase & Keterangan \\
\hline 1 & $95-100$ & 6 & $21,43 \%$ & \multirow{4}{*}{ Tuntas } \\
\hline 2 & $85-94$ & 16 & $57,14 \%$ & \\
\hline 3 & $80-84$ & 3 & $10,71 \%$ & \\
\hline 4 & $75-79$ & 1 & $3,58 \%$ & \\
\hline 5 & $\leq 74$ & 2 & $7,14 \%$ & Belum Tuntas \\
\hline \multicolumn{2}{|c|}{ Jumlah } & 28 & $100 \%$ & - \\
\hline \multicolumn{4}{|c|}{ Rata-rata } & 85,36 \\
\hline \multicolumn{4}{|c|}{ Nilai Tertinggi } & 100 \\
\hline \multicolumn{4}{|c|}{ Nilai Terendah } & 70 \\
\hline
\end{tabular}




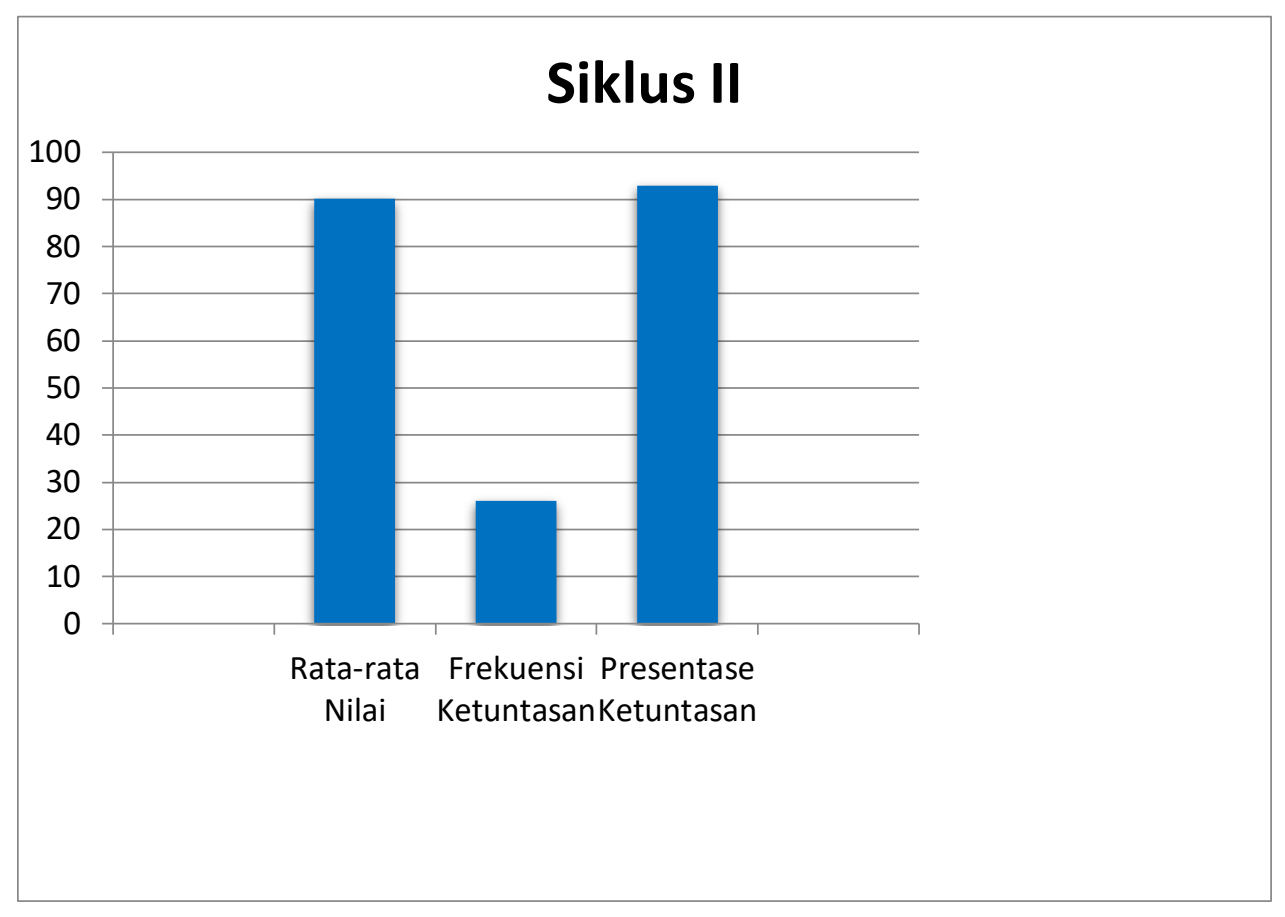

Grafik 3. Siklus II

Pengamatan nilai hasi belajar pada siklus II menunjukkan bahwa dari 28 siswa terdapat 26 siswa atau 92,86\% yang tuntas dengan mendapatkan nilai di atas KKM dan 2 siswa atau $7,14 \%$ yang belum tuntas dan mendapatkan nilai di bawah KKM. Siswa yang mendapatkan nilai 95-100 ada 6 dengan keterangan (Tuntas) dengan persentase 21,43\%. Siswa yang mendapat nilai 85-94 ada 16 siswa dengan keterangan (Tuntas) dengan presentase $57,14 \%$. Siswa yang mendapat nilai $80-84$ ada 3 dengan keterangan (Tuntas) dengan presentase $10,71 \%$. Siswa yang mendapat nilai $75-79$ ada 1 dengan keterangan (Tuntas) dengan presentase 3,58\%. Siswa yang mendapatkan nilai di bawah KKM ada 2 peserta didik dengan keterangan (Belum Tuntas) dengan presentase 7,14\%. Karena hasil yang diperoleh sudah memenuhi indikator keberhasilan, maka peneliti tidak perlu melanjutkan pada siklus berikutnya.

Media interaktif mendorong siswa untuk terlibat secara aktif dalam proses pembelajaran, baik dalam interaksi siswa dengan media pembelajaran, siswa dengan siswa, maupun siswa dengan guru (Rosamsi, Miarsyah, \& Ristanto, 2019). Media interaktif yang berupa video pembelajaran telah menarik siswa untuk memperhatikan penjelasan yang ditampilkan dalam video tersebut dan rupanya siswa lebih mudah memahami dibanding dengan mendengarkan ceramah guru.

\section{KESIMPULAN}

\section{Simpulan}

Penggunaan media interaktif merupakan media pembelajaran yang efektif dalam meningkatkan pemahaman siswa. Hal ini didasarkan dari hasil penelitian yang menunjukkan adanya peningkatan rata-rata hasil belajar materi sistem peredaran darah manusia pada siswa kelas VI SD Negeri Balesari Kecamatan Bansari Kabupaten Temanggung tahun pelajaran 2018/2019, dapat disimpulkan bahwa hasil belajar mengalami peningkatan yang cukup baik. Hal ini dapat dilihat dari hasil evaluasi pada kondisi awal yang semula nilai rata-ratanya 55 dengan ketuntasan sebanyak 7 siswa dengan persentase $25 \%$ meningkat pada siklus I nilai rata-rata yang diperoleh adalah 71,50 dengan ketuntasan sebanyak 16 siswa dengan persentase 57,14\% kemudian pada siklus ke II diperoleh rata-rata nilai sebanyak 85,36 dengan ketuntasan sebanyak 26 siswa 
dengan persentase $92,86 \%$.

\section{Saran}

Pada akhir penelitian ini penulis dapat memberikan saran-saran :

Bagi Guru :

1. Dalam proses pembelajaran hendaknya menggunakan media pembelajaran supaya lebih menarik, memudahkan siswa dalam memahami materi.

2. Memberikan kesempatan kepada siswa untuk selalu aktif dalam pembelajaran.

3. Selalu mengadakan tukar pendapat dengan teman sejawat dan Kepala Sekolah untuk pencapaian keberhasilan belajar.

Bagi Siswa :

1. Siswa sebaiknya dalam mengikuti proses pembelajaran dapat aktif dan semangat memperhatikan materi yang disajikan dalam video pembelajaran sehingga benar-benar memahami materi tersebut.

2. Siswa hendaknya belajar sungguh-sungguh supaya hasil belajarnya meningkat.

\section{DAFTAR PUSTAKA}

Arif Sukadi Sadiman. Beberapa Aspek Pengembangan Sumber Belajar. (Cet; Jakarta : Mediyatama Sarana Perkasa, 1946) h. 109

Arikunto, S. (2009). Dasar-Dasar Evaluasi Pendidikan (edisi revisi). (Cet. IX; Jakarta : Bumi Aksara. 118-137

Amran Ys Chaniago. (2002) Kamus Lengkap Bahasa Indonesia. (Cet.V; Bandung : Pustaka Setia, 2002) h. 427-428

Ihayati Yayat. (2008). Ilmu Pengetahuan Alam : SD/MI Kelas VI. Jakarta : Pusat Perbukuan, Departemen Pendidikan Nasional

Nisa, A., Djamahar, R., \& Evriyani, D. (2015). Effect of application of ular tangga game media on cognitive learning result of human reproductive system. Biosfer: Jurnal Pendidikan Biologi, 8(2), 20-26.

Nurinayati, F., Sartono, N., \& Evriyani, D. (2014). Development of Digital Comic as Learning Media on Immune System Topic in SMAN 13 Jakarta. Biosfer: Jurnal Pendidikan Biologi, 7(2), 47-52.

Komala, R., Suryanda, A., \& Lismana, D. D. (2016). Pengembangan paludarium sebagai media pembelajaran biologi pokok bahasan ekosistem di sma. Biosfer: Jurnal Pendidikan Biologi, 9(1), 10-14.

Ristanto, R. H. (2011). Pembelajaran biologi berbasis inkuiri terbimbing dengan multimedia dan lingkungan riil terhadap prestasi belajar. Educatio, 6(1), 53-68.

Rosamsi, S., Miarsyah, M., \& Ristanto, R. H. (2019). Interactive multimedia effectiveness in improving cell concept mastery. Journal of Biology Education, 8(1), 56-61.

Sulistiyanto Heri. (2008). Ilmu Pengetahuan Alam 6 : Untuk SD dan MI Kelas VI. Jakarta : Pusat Perbukuan, Departemen Pendidikan Nasional 